\title{
The Effects of Zigzag Ladder Exercise Crossover Shuffle, In Out Shuffle and Ali Shuffle Against Speed and Agility
}

\author{
Afryan Pandarwidi S1,a, Gigih Siantoro', Amrozi Khamidi ${ }^{1}$ \\ ${ }^{1}$ Masters of Sport Education, Universitas Negeri Surabaya, Surabaya, Indonesia \\ a afryanpandarwidhy@gmail.com \\ ${ }^{*}$ Corresponding Author:
}

How to Cite : Panwarwidi S., A., Siantoro, G \& Khamidi, A. (2020). The Effects of Zigzag Ladder Exercise Crossover Shuffle, In Out Shuffle and Ali Shuffle Against Speed and Agility. International Journal for Educational and Vocational Studies, 2 (1), 109-114. DOI: https://doi.org/10.29103/ijevs.v2i1.2040

\section{ARTICLE HISTORY}

Received: 25 Novemer 2019

Revised: 14 December 2019

Accepted: 16 January 2020

\section{KEYWORDS}

Training;

Ladder Zigzag crossover shuffle;

In out shuffle;

Ali shuffle;

Speed;

Agility;

\begin{abstract}
The purpose of this study was to analyze: (1) the effect of the Ladder Zigzag crossover shuffle exercise on speed and agility; (2) the effect of the Ladder In out shuffle exercise on speed and agility; (3) the effect of the Ladder Ali shuffle exercise on speed and agility; (4) differences in the influence of Ladder Zigzag crossover shuffle, In out shuffle and Ali shuffle on speed and agility. This type of research is quantitative with quasi-experimental methods. The research design used is maching only design and data analysis using t-test and ANOVA. Retrieval of data using a sprint 30 meters to measure speed and agility t-test to measure agility at the time of the pretest and posttest. The results showed that the difference between the pretest and posttest of each group were: (1) experimental group I for speed $=0.787$ and agility $=0.731$ (2) experimental group II for speed $=0.866$ and agility $=0.881$ (3) experimental group III for speed $=0.863$ and agility $=0.84$ (4) the control group for speed $=0.115$ and agility $=0.118$. Based on the above analysis, it can be concluded that there was an increase in speed and agility for each group after being given the Ladder Zigzag crossover shuffle, In out shuffle and Ali shuffle exercises seen from the t-test. In addition, through the ANOVA test, where the Ladder Zigzag crossover shuffle, In out shuffle and Ali shuffle exercises had a better effect than the control group.
\end{abstract}

This is an open access article under the CC-BY-SA license.

\section{INTRODUCTION}

In carrying out an exercise there is a physical condition of some components that can not be separated, both the improvement and maintenance. The main purpose of preparing physically in training is to increase the functional potential of athletes and develop biomotoric abilities to the highest standards. The development of physical training in each exercise program is carried out through general physical stages, special physical preparation and building a high level of biomotor ability (Bompa 2009: 61). The components of physical condition in question are strength, endurance, explosive power, speed, flexibility, agility, accuracy, reaction, balance, and coordination.

Based on the components of these physical conditions, cornered researchers focus on the components of speed and agility. Because it is an element of physical training that cannot be separated and is very much needed in many sports. According to Ratamess (2012), speed is the ability to make similar movements in a row in the shortest possible time. Hidayat (2014), said that speed is the capacity of movement of a limb or part of the body lever system or the speed of movement of the whole body which is carried out in a short time. While Agility is the ability to move direction and change body position quickly and effectively and under control, and requires integrity of movement skills by using a combination of balance, coordination, speed, reflexes, strength, endurance, and stamina (Sheppard \& Young) in Hsiu-Ching, and Yee-Pay, (2012). Agility is not a single physical ability, but is composed of components of balance, coordination, speed, reflexes, strength, endurance, and stamina. These components interact with each other. An athlete's agility in changing body movements quickly is a basic component in team or team sports such as futsal and soccer. Because during the match, players perform movements such as running and change direction of movement quickly both in dribbling the ball and blocking the enemy's movements, (Milanovic et al. 2011).

In recent years as the development of the sporting world has developed a form of training method known as a ladder drill. Ladder drill is a form of training used to train SAQ (Speed, Agility, and quickness) involving progressive prescription training to develop an athlete's ability to be more skilled at faster and more precise speeds. Speed, 
agility, and quickness exercises allow athletes to better react to stimuli, start faster and more efficiently, move effectively in various directions, and change directions or stop quickly to make an action in a fast, smooth, efficient, and repeatedly (Polman et al., 2009: 495). has become a popular way to train athletes' physical components especially agility. With increasing needs, this type of training has been proven to improve one's abilities in a variety of sports.

This exercise uses a tool called a ladder, this tool is shaped like a ladder containing ladder boxes, this box will later be used as a footrest. Ladder training allows coaches and players to be imaginative and this exercise can also have a pleasant effect (Srinivasan, 2013: p.15). This training starts with general development to the development of sophisticated skills, from a variety of small movements, faster movements. Given the working principle of slow and controlled movements and moving quickly, explosive movements that are used as development teaching and learning will have a greater chance of success (Rajendran, 2016. p.99). ). Ladder drill is better done early after warming up, when the muscles have not experienced significant exhaustion or are still fresh in order to carry out good quality movements (Khatri, 2015: p.1). Kathri (2015) also added that there are 4 basic skills that are used when training with stairs or ladderdrill, namely running, passing, shuffle and jumping / hops (Kathri, p.1). kind, shuffle such as zigzag crossover shuffe, In-out shuffle and Ali shuffle This exercise can increase speed and agility, this is in accordance with the opinion of Dhanaraj (2014), suggesting that ladder training has a significant effect in increasing speed and agility.

Especially for male students of SMP Negeri 1 Bungah who take part in extracurricular activities the majority prefers sports branches that require speed and agility such as soccer, futsal, and athletics in the run number. Based on the observations of researchers and observations from several sports that have been followed by students for example, such as national student sports (O2sn) Olympiad activities at the district level include athletics in 100 meter running numbers and the Indonesian student league (Lpi) category of football in all districts, that junior high school students Negeri 1 Bungah who took part in this extracurricular activity had the potential to achieve an achievement, but the students' physical work abilities were not optimal due to lack of physical training, they were never even given training methods to improve physical abilities. So training to improve physical condition is very important to achieve the best performance in an achievement. Of all the sports that students take in extracurricular activities, that the more dominant ones to be improved are speed and agility.

Based on the background description above, the researcher wants to provide an alternative exercise in the form of a Ladder drill training program, to improve physical conditions, especially in increasing speed and agility in accordance with the needs of sports extracurricular activities participated by male students of
SMP Negeri 1 Bungah. This program has not been trained and carried out. On this basis, the writer is interested and motivated to want to conduct research that focuses on speed and agility using Zigzag crossover shuffe ladder drill, In-out shuffle and Ali shuffle researchers want to study and analyze whether the exercise is able to increase the speed and agility of junior high school students Land 1 Bungah.

\section{METHODS}

This type of research uses a quantitative approach. The research method used was quasi-experimental. Experimental research is research conducted strictly to determine the causal relationship between variables (Maksum, 2012: 65). Experiment is a type of research in which the sample or object of research is given a treatment to determine the cause and effect between variables. This study aims to determine the effect of zigzag ladder crossover shuffle, in out shuffle and ali shuffle exercises on increasing speed and agility.

\subsection{Population and Samples}

The population in this study were all male students of class VIII and IX of SMP Negeri 1 Bungah who were actively registered in sports extracurricular activities. In this study the sample was class VIII and IX students of SMP Negeri 1 Bungah who were actively registered in sports extracurricular activities by 32 people. Research Instruments

\subsection{Treatment Instruments}

The data in this study were obtained from the results of tests and measurements made on the study sample. Components of tests and measurements carried out in this study are: speed test, and agility test. The speed test uses a 30 meter sprint test, and the agility test uses a T-test.

\subsection{Data Analysis}

To analyze the acquisition of data about training using agility and speed tests. Then the test results will be recorded and calculated using the Analysis of Variance (ANOVA) test with $\alpha=0.05$ (Maksum, 2012, p.161).

To meet the assumptions in the ANOVA technique, a Normality and Homogeneity test was performed with the IBM SPSS Statistics 21.0 application.

\section{RESULTS AND DISCUSSION}

This chapter will describe the data description, the terms of hypothesis testing and the results of hypothesis testing. Description of the data presented in the form of pre-test and post-test results were given treatment in each experimental group, the data included data on the results of agility and speed tests. While the experimental groups in this study include: Group I Ladder Zigzag Crossover Shuffle, Group II Ladder In-Out Shuffle, Group III Ladder Ali Shuffle and Group IV control. This research was 
conducted on students who took extracurricular activities at SMPN 1 Bungah with 32 students divided into 4 groups.

\subsection{Experiment Group I Data Description (Ladder Zigzag Crossover Shuffle)}

Based on the results of measurements in the experimental group I can be seen that there is an increase in the mean value between pretest and posttest on the dependent variable. This is evident from the average posttest and pretest mean values. Where can be seen that the average value for the speed of the posttest measurement results ( $36.49 \mathrm{sec})$, this looks faster than the results of the pretest measurement $(42.79 \mathrm{sec})$ and the agility of the posttest measurement results $(96.07 \mathrm{sec})$, this looks faster compared to the results of the pretest measurement of (101.92 sec). In giving treatment to group I can be illustrated in the following diagram:

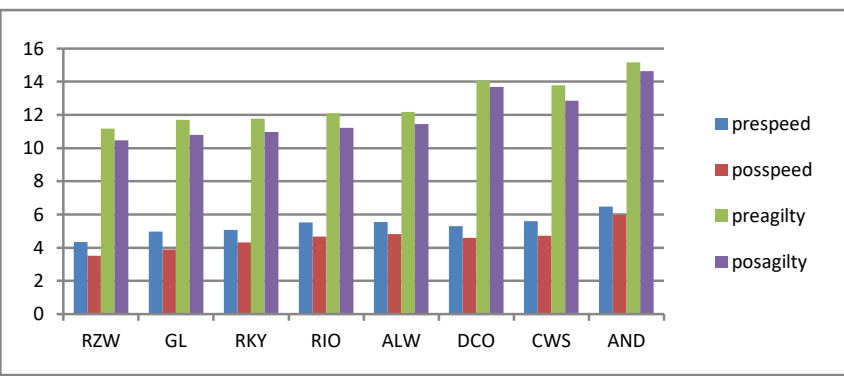

Figure 1. Diagram results of a Zigzag crossover shuffle ladder drill

\subsection{Description of Experiment Group II data (Ladder In-Out Shuffle)}

Based on the results of measurements in the experimental group II can be seen that there is an increase in the mean value between pretest and posttest on the dependent variable. This is evident from the average posttest and pretest mean values. Where can be seen that the average value for the speed of the posttest measurement results ( $35.95 \mathrm{sec})$, this looks faster than the results of the pretest measurement $(42.88 \mathrm{sec})$ and the agility of the posttest

measurement results of $(95.1 \mathrm{sec})$, this looks faster compared to the results of the pretest measurement of (102.15 sec). In giving treatment to group I can be

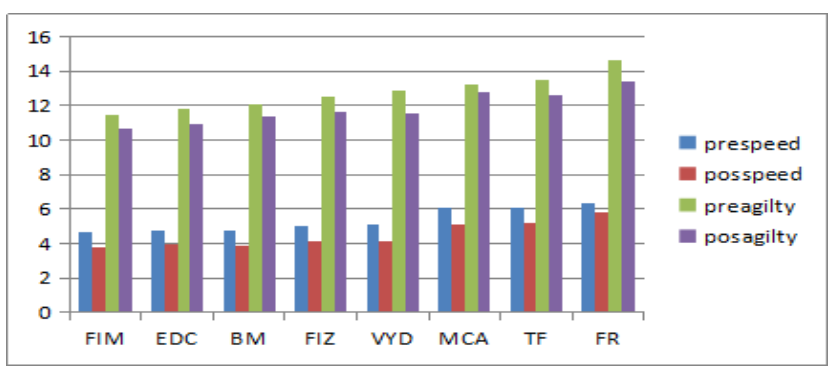

illustrated in the following diagram:

Figure 2. Diagram of the results of a ladder drill drill out shuffle

\subsection{Description of Experiment Group III Data (Ladder Ali Shuffle)}

Based on the results of measurements in the experimental group III it can be seen that there is an increase in the mean value between pretest and posttest on the dependent variable. This is evident from the average posttest and pretest mean values. Where can be seen that the average value for the speed of the posttest measurement results $(35.89 \mathrm{sec})$, this looks faster than the results of the pretest measurement $(42.8 \mathrm{sec})$ and the agility of the posttest measurement results of $(95.39 \mathrm{sec})$, this looks faster compared to the results of the pretest measurement of (102.11 sec). In giving treatment to group I can be illustrated in the following diagram:

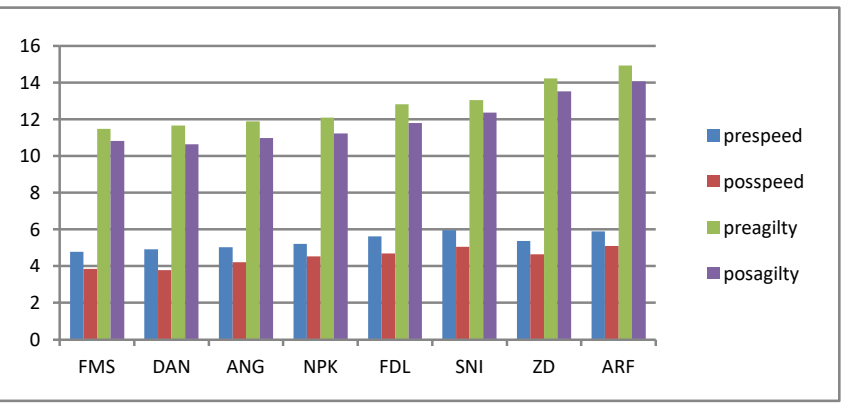

Figure 3. Diagram of the Ali shuffle Ladder drill results

\subsection{Description of Group IV Data (Control Group)}

Based on the results of measurements in the experimental group III it can be seen that there is an increase in the mean value bteween pretest and posttest on the dependent variable. This is evident from the average posttest and pretest mean values. Where can be seen that the average value for the speed of the posttest measurement results $(42.3 \mathrm{sec})$, this looks faster than the results of the pretest measurement $(43.22 \mathrm{sec})$ and the agility of the posttest measurement results $(100.29 \mathrm{sec})$, this looks faster compared to the results of the pretest measurement of (101.24 sec). In giving treatment to group I can be illustrated in the following diagram:

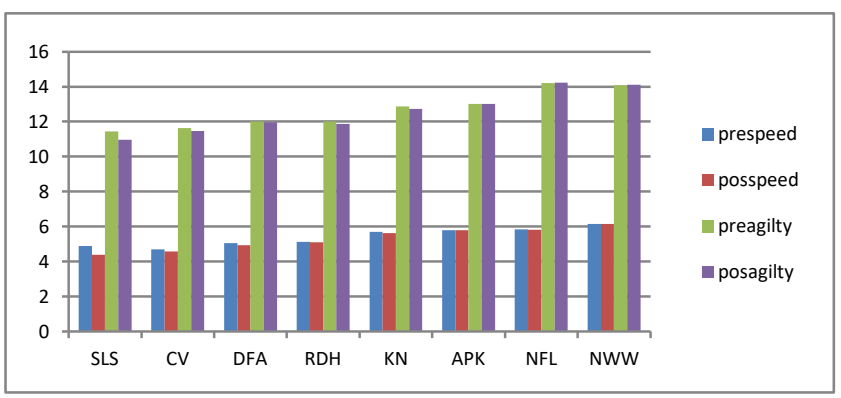

Figure 4. Diagram of control results

\subsection{E. Recapitulation of the average results of the exercises in each group}


Table 1. Average Results of Exercises in Each Group

\begin{tabular}{lccccc}
\hline \multirow{5}{*}{ Mean Measurement } & \multicolumn{3}{c}{ Group of Ladder drill } & & \\
\cline { 2 - 6 } & \multicolumn{1}{c}{$\begin{array}{c}\text { Zig zag } \\
\text { crossover } \\
\text { shuffle }\end{array}$} & $\begin{array}{c}\text { In } \\
\text { shuffle }\end{array}$ & $\begin{array}{c}\text { Ali } \\
\text { shuffle }\end{array}$ & Control \\
\hline \multirow{2}{*}{$\begin{array}{l}\text { Speed } \\
\text { (scn) }\end{array}$} & pretest & 42,79 & 42,88 & 42,8 & 43,22 \\
\cline { 2 - 6 } & posttest & 36,49 & 35,95 & 35,89 & 42,3 \\
\hline \multirow{2}{*}{ Agility (scn) } & pretest & 101,92 & 102,15 & 102,11 & 101,24 \\
\cline { 2 - 6 } & posttest & 96,07 & 95,1 & 95,39 & 100,29 \\
\hline
\end{tabular}

From the above table, it can be seen that the provision of the Ladder drill in out shuffle training in the experimental group II turned out to provide the best speed and agility improvement than the other three groups, namely group I Zig zag ladder drill crossover shuffle, Ali shuffle and control group III. For the average results of the experimental group can be illustrated in the diagram as follows:

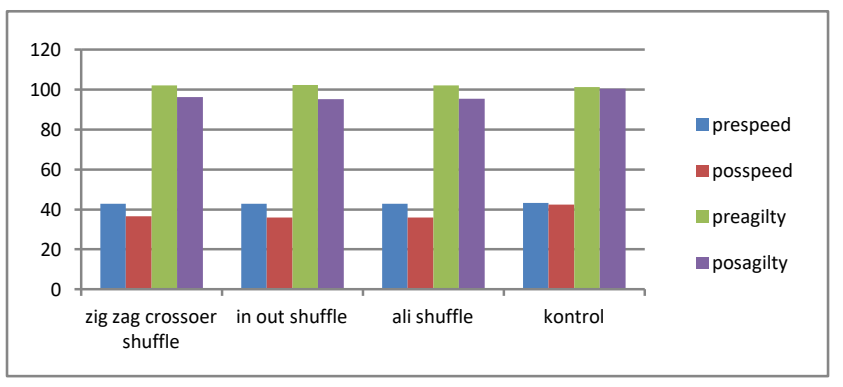

Figure 5. Diagram of the results of a ladder drill drill out shuffle

\section{CONCLUSION}

Based on the results of research and discussion that has been described in the previous chapter, it can be summarized as follows:

1. There is a significant effect on Slaloms ladder drill training on speed and agility.

2. There is a significant effect on Carioca's ladder drill training on speed and agility.

3. There is a difference in effect between the Slaloms ladder drill and the Carioca ladder drill on increasing speed.

4. There is no difference in effect between the Slaloms ladder drill and the Carioca ladder drill on increasing agility.

\section{REFERENCES}

Arikunto, S. (2010). Prosedur Penelitian. Jakarta: PT. Renika Cipta.

Arjunan, R. (2015). Effect of Speed, Agility and Quickness (S. A. Q) Training on SelectedPhysical Fitness Variables Among School Soccer Players. International Journal of Research in Humanities, Arts and Literature (IMPACT:
IJRHAL). Vol. 3, Issue 10.

Atanasković, Andrija\& Martin Georgiev. (2013). The Impact of Plyometric Training on the Explosive Power of the Lower Extremities of Handball Player. Sport Science \& Practice. Vol. 3, no.1.

Budiwanto, S. (2012). Metodologi Latihan Olahraga. Malang: UM Press

Bompa, and Haff, G, (2009). TheoryandMethodologyofTraining. United States : Human Kinetics.

Bompa, Tudor O \& Carlo Buzzichelli. (2015). Periodization Training for Sports. Third Edition. United States : Human Kinetics.

Brown, Lee E., \& Vance A. Ferrigno. (2005). Training for Speed, Agility, and Quickness. 2nd ed. United States: Human Kinetics.

Chandrakumar, N. \& C. Ramesh. (2015). Effect of ladder drill and SAQ training on speed and agility among sports club badminton players. International Journal of Applied Research. 1(12): 527-529.

Clark, Micheal A., Scott C. Lucett, \& Brian G. Sutton. (2012). NASM Essentials of Personal Fitness Training. Fourth Edition. Philadelpia: Lippincott Williams \& Wilkins, a Wolters Kluwer business.

Dawes, Jay \& Mark Roonzen. (2012). Developing Agility and Quickness. Australia: Human Kinetics.

Emeish, Mohamed Kamal. (2015). Effect of S.A.Q Exercises on Certain Physical Variables and JumpShotin Handball. Science, Movement and Health, Vol. XV, ISSUE 2.

Erčulj, Frane, Mitja Bračič, \& Saša Jakovljević. (2011). The Level of Speed and Agility of Different Types of Elite Female Basketball Players. Physical Education and Sport. Vol. 9, No 3.

Haff, Gregory G., \& N. Travis Triplett. (2016). Essentials of Strength Training and Conditioning. United States: Human Kinetics.

Haff, Gregory G., \& Sophia Nimphius. (2012). Training Principles for Power. Strength and Conditioning Journal. Volume 34, Nomor 6.

Haci Murat Sahin. 2014. Relationships Between Acceleration, Agility, And Jumping Ability In FemaleVolleyball Players. Www.Pelagiaresearchlibrary.Com.

Hidayat, S. (2014). Pelatihan Olahraga: Teori dan Metodologi.Yokyakarta. Graha Ilmu.

Horička, Pavol.,JánHianik, \&JaromírŠimonek. (2014). The Relationship Between Speed Factors and Agility in Sport Games. Journal of Human Sport \& Exercise. Volume 9. Issue 1.

Hsiu-Ching Lin, Yee-Pay Wuang. 2012. StrengthAnd Agility Training In Adolescents With DownSyndrome:ARandomizedControlledTrial.Www.Sci 
encedirect.Com

Jamil, Syarulniza Abdul, Nurhani Aziz, \& Lim Boon Hooi. (2015). Effects Of Ladder Drills Training On Agility Performance. International Journal of Health, Physical Education and Computer Science in Sports. Volume No.17, No.1.

Johnson, P. \& Bujjibabu, M. (2012). Effect of Plyometric and Speed Agility and Quickness (SAQ) on Speed and Agility of Male Football Palyers. Asian Journal of Phisical Education and Computer Science in Sport. Volume. 7 No.1 pp 26-30.

Jovanic, Mario, Goran Sporis, Darija Omrcen, \& Fredi Fiorentini. (2011). Effects of Speed, Agility, Quickness Training Method on Power Performance In Elite Soccer Players. Journal of Strength and Conditioning Research. Volume 25. Number 5.

Joyce, David, \& Daniel Lewindon. (2014). High-performance training for sports. United States: Human Kinetics.

Karthick, M., Radhakrishnan, \& Kishore Kumar. (2016). Effects of Saq Training on Selected Physical Fitness Parameters And Kicking Ability of High School Level Football Players. International Journal of Applied Research; 2(7): 600-602.

Kenney, Larry, Jack H. Wilmore, \& David L. Costill. (2012). Physiology of Sport and Exercise. Fifth Edition. United States: Human Kinetics.

Khatri, Akash, \&V.Vallimurugan. (2015). Effect of Ladder Training on Selected Psychological Variables among Kho-Kho Players. International Journal of Recent Research and Applied Studies. Volume 2,Issue 4(1).

Kodgire, UshaDnyanoba. (2014). Comparative Effect f SAQ and Circuit Training Programme on Selected Physical Fitness Variables of School Level Kho -Kho Players. Academic Sports Scholar. Volume 3. Issue 8.

Kusnanik, N.W., Nasution, J., dan Hartono, S. (2011). Dasar-dasar FisiologiOlahraga. Unesa: Unesa University Press.

Lee, Buddy. (2010). Jump Rope Training. 2nd ed. United States: Human Kinetics.

Maksum, Ali. (2012). Metodologi PenelitiandalamOlahraga. Surabaya: Unesa University Press.

Mathisen, Gunnar Elling \& Svein Arne Pettersen. (2015). The Effect of Speed Training on Sprint andAgility Performance in 15-Year-Old Female Soccer Players. Lase Journal of Sport Science. 6/2.

Meethal, Atul, \& Haary Benny Chettiamkudiyil. (2015). Effect of Plyometric Training and SAQ Training Followed By Detraining on Agility of Intercollegiate Level Footballers. International Journal of Physical Education, Fitness and Sports. Vol. 4. No. 2.

Milanovic, Zoran, et.al. (2014). Does SAQ Training Improve the Speed and Flexibility of Young Soccer Players? A Randomized Controlled Trial. Human Movement Science 38 197-208.
Milenković, Dejan. (2011). Speed As an Important Component Oof Football Game. Acta Kinesiologica 5. 1: 57-61.

Mylsidayu, A. \& Kurniawan, F. (2015). Ilmu Kepelatihan Dasar. Bandung: Alfabeta.

Nagarajan, dkk. (2013). "Effect Of Aerobic Circuit Training And Parcours Training On Selected Physiological Variables Among College Men Student”. Journal International, Vol.11, 1 PP 149-151.

Raghuram, R., \&I. Devi Vara Prasad.(2016). Analysis of the Changes in Selected Speed and Power Parameters in Response to Assisted and Resisted Sprint Training among Male Sprinters. International Journal of Recent Research and Applied Studies. Volume 3, Issue 10.

Rajendran, K. (2016). Effect of Ladder Training on Agility among College levelFootball Players. International Journal of Recent Research and Applied Studies. Volume 3, Issue 4 (23).

Rajkumar, R., \&K.Divya. (2016). Effect of SAQ Training on Selected Physical Responses Among College Men Students. Indian Journal of Applied Research. Volume:6, Issue:8.

Ratamess, Nicholas. (2012). ACSM's Foundations of Strength Training and Conditioning. Indianapolis. Lippincott Williams \& Wilkins.

Sahin, Haci Murat. (2014). Relationships Between Acceleration, Agility, and Jumping Ability in FemaleVolleyball Players. European Journal of Experimental Biology: 4(1):303-308.

Schirm, Matthew. (2011). http://www.livestrong.com. Diaksestanggal10Januari 2017.

Sethu, S. (2014). Comparison of Plyometric Training and Ladder Training on Sprinting Speed, Vertical Explosive Power and Agility. International Journal of Recent Research and Applied Studies. Volume 1,Issue 1(15).

Sharma, Sandeep, \& Mahesh Singh Dhapola. (2015). Effect of Speed, Agility, Quickness (SAQ) Training Programme on Selected Physical Fitness Variables and Performance Ability in Basketball University Players. International Educational E-Journal. Volume-IV, Issue-III.

Sporis, Goran, Zoran Milanović, Nebojša Trajković and Aleksandar Joksimović. (2010). Correlation Between Speed, Agility and Quickness (SAQ) In Elite Young Soccer Players. Acta Kinesiologica: 2: 36-41.

Srinivasan, M. (2013). Influence of Conventional Training Programme Combined With Ladder Training on Selected Physical Fitness and Skill Performance Variables of College Level Badminton Players. International Journal of Behavioral Social and Movement Sciences. Vol.02,Issue03.

Sucharitha, B.S. dkk (2014). "Effectiveness of plyometric training on anaerobic power and agility in female badminton players". International journal Of Pharmaceutical Research and Bio Science. ISSN: 2277-8713, Volume 3 No 4. Pp 754-761. 
Sugiyono. (2010). Statistika untuk Pendidikan. Bandung:Alvabeta.

Sugiyono.(2011). Metode Penelitian Kuantitatif dan Kualitatif dan R \& D. Bandung: Alvabeta.

Sukadiyanto dan Muluk, D. (2011). Pengantar Teori dan Metodologi Melatih Fisik. Bandung: Lubuk Agung.

Suresh, A. \& S. Bevinson Perinbaraj. (2016). Effect of SAQ Training Associated with Speed Training on Agility Explosive Power and Speed among Engineering College Sports Persons. International Journal of Recent Research and Applied Studies. Volume 3, Issue 6 (12). 